\title{
Analysis Health Information Systems Quality on the Effectiveness of Public Health Center Officers in Ambon City
}

\author{
Erwine Senda N Wattimena ${ }^{1}$, Amran Razak ${ }^{2}$, Sukri Pallutturi² ${ }^{2}$ Darmawansyah ${ }^{2}$ Muhammad Syafar $^{3}$, \\ Lalu Muhammad Saleh ${ }^{4}$, Suci Rahmadani ${ }^{2}$ \\ ${ }^{1}$ Research Scholar Magister Program Departement of Health Adminitration and Policy, Public Health Hasanuddin \\ University, ${ }^{2}$ Professors, Departement of Health Adminitration and Policy, Public Health Hasanuddin University, \\ ${ }^{3}$ Professors of Departement of Health Promotion and Behavior, Public Health Hasanuddin University, ${ }^{4}$ Lecturer of \\ Departement Occupational Safety and Health, Public Health Hasanuddin University
}

\begin{abstract}
Health information systems play a role in providing data, information and health indicators to support the management process will have an impact on increasing the effectiveness of work. The purpose of this research is to know the quality influence of health information system that is seen from availability, timeliness, and relevance to the effectiveness of employees of public health centers in Ambon City. The type of research used is quantitative with cross sectional study design. The population in this study is all employees of the Ambon City Public Health Center amounting to 586 people, the withdrawal of samples with purposive technique obtained by 50 people. Collection of data through questionnaires. Data is analyzed by chi-square test. The results showed that the health information system of the availability aspect $(\mathrm{P}=0.02)$, timely $(\mathrm{P}=$ $0.01)$ and relevant $(\mathrm{P}=0.04)$ significantly affected the effectiveness of healthcare personnel working in the Public health center in Ambon city. It is hoped that the public health center in Ambon City can improve the existing system so that the information produced is more quality.
\end{abstract}

Key Words: Health information System, availability, and health care management.

\section{Introduction}

Efforts in the implementation of health development are all components of the nation that have been arranged in a system called the National Health System (NHS). Its components consist of seven subsystems, one of them about management, information and health regulations. To ensure the achievement of national development objectives of health system is a manifestation and implementation method of health development that combines various efforts of Indonesian nation in a single step ${ }^{1}$.

Health information systems can integrate data collection, reporting, processing and use of information to improve the efficiency and effectiveness of healthcare through good management at all levels of health in the central, provincial, Regency/city or even at the level of technical implementation such as hospitals and public health centers ${ }^{2}$.
Public health centers as the lowest health executor have difficulty in reporting, where data between one report from one program with another report from other programs has almost the same data set. On the other hand, the application to make various reports is different, causing overlap in its workmanship, it takes a system of information ${ }^{3}$.

In the implementation of generic SIKDA for the Maluku province as many as 26 public health centers and 22 public health centers in Ambon City must develop a computer-based health information system in the hope that the data and information produced can be integrated so that the efficiency and effectiveness of the work increases. Based on data from employees work in the Community Health center in Ambon in 2019 repeated errors, the default standard of the report is not used, the delay of information (report) in the form of data (achievement/target) program needed in the creation of public health center profile. Looking at the background 
picture researchers want to know the implementation of regional health Information System application (SIKDA) generic Public health center in Ambon City.

\section{Materials and Method}

This research uses quantitative research methods of cross-sectional study design. The population in this study was all employees of the public health centers in Ambon city, amounting to 586 people. The sample is determined by purposive method. Sample criteria is the employee who served in the Community Health center in Ambon city that has participated in the training of regional Health information system (SIKDA generic) amounting to 50 people. Data collection is obtained through a live interview using a questionnaire.

\section{Result}

Based on table 1 shows that the most recent education of respondents was D III with 22 respondents (44.0\%) while the least were D I and D IV, each with 1 respondent (2\%). The length of service is the length of time the respondent has been working since he was an employee. Table 1 shows that the length of service for most respondents 1-10 years was 34 respondents $(68.0 \%)$, while those with a minimum of $21-30$ years were 2 respondents (4.0\%). Most of the respondents' gender was 43 respondents $(86.0 \%)$, while men were 7 respondents $(14.0 \%)$. The highest age group of respondents is $31-40$ years with 22 respondents $(44.0 \%)$, the least is $41-50$ years, with 2 respondents (4\%).

Table 1: Frequency Distribution of Characteristics of Respondents in Ambon City community health centers in $\mathbf{2 0 2 0}$

\begin{tabular}{|c|c|c|c|}
\hline \multirow{3}{*}{$\begin{array}{l}\text { Characteristics of } \\
\text { Respondents } \\
\text { Gender }\end{array}$} & \multirow{3}{*}{$\begin{array}{l}\text { Category } \\
\text { Male } \\
\text { Girl }\end{array}$} & \multirow{2}{*}{\multicolumn{2}{|c|}{$\begin{array}{l}\text { total } \\
\mathrm{N}=\mathbf{5 0} \%\end{array}$}} \\
\hline & & & \\
\hline & & $\begin{array}{l}7 \\
43\end{array}$ & $\begin{array}{l}14.0 \\
86.0\end{array}$ \\
\hline $\begin{array}{l}\text { Age } \\
\text { (Year) }\end{array}$ & $\begin{array}{l}21-30 \\
31-40 \\
41-50 \\
51-60\end{array}$ & $\begin{array}{l}21 \\
22 \\
2 \\
5\end{array}$ & $\begin{array}{l}42.0 \\
44.0 \\
4.0 \\
10.0\end{array}$ \\
\hline Education & $\begin{array}{l}\text { High school } \\
\text { D I } \\
\text { D III } \\
\text { D IV } \\
\text { S1 } \\
\text { S2 }\end{array}$ & $\begin{array}{l}3 \\
1 \\
22 \\
1 \\
20 \\
3\end{array}$ & $\begin{array}{l}6.0 \\
2.0 \\
44.0 \\
2.0 \\
40 \\
6.0\end{array}$ \\
\hline Old Service & $\begin{array}{l}1-10 \text { years } \\
11-20 \text { years } \\
21-30 \text { years } \\
31-40 \text { years }\end{array}$ & $\begin{array}{l}34 \\
9 \\
2 \\
5\end{array}$ & $\begin{array}{l}68.0 \\
18.0 \\
4.0 \\
10.0\end{array}$ \\
\hline
\end{tabular}

Source:Primary Data, 2020 
Table 2: Effect of Information Availability, timeliness and relevance information on Employee Work Effectiveness in Ambon City community health centers in 2020

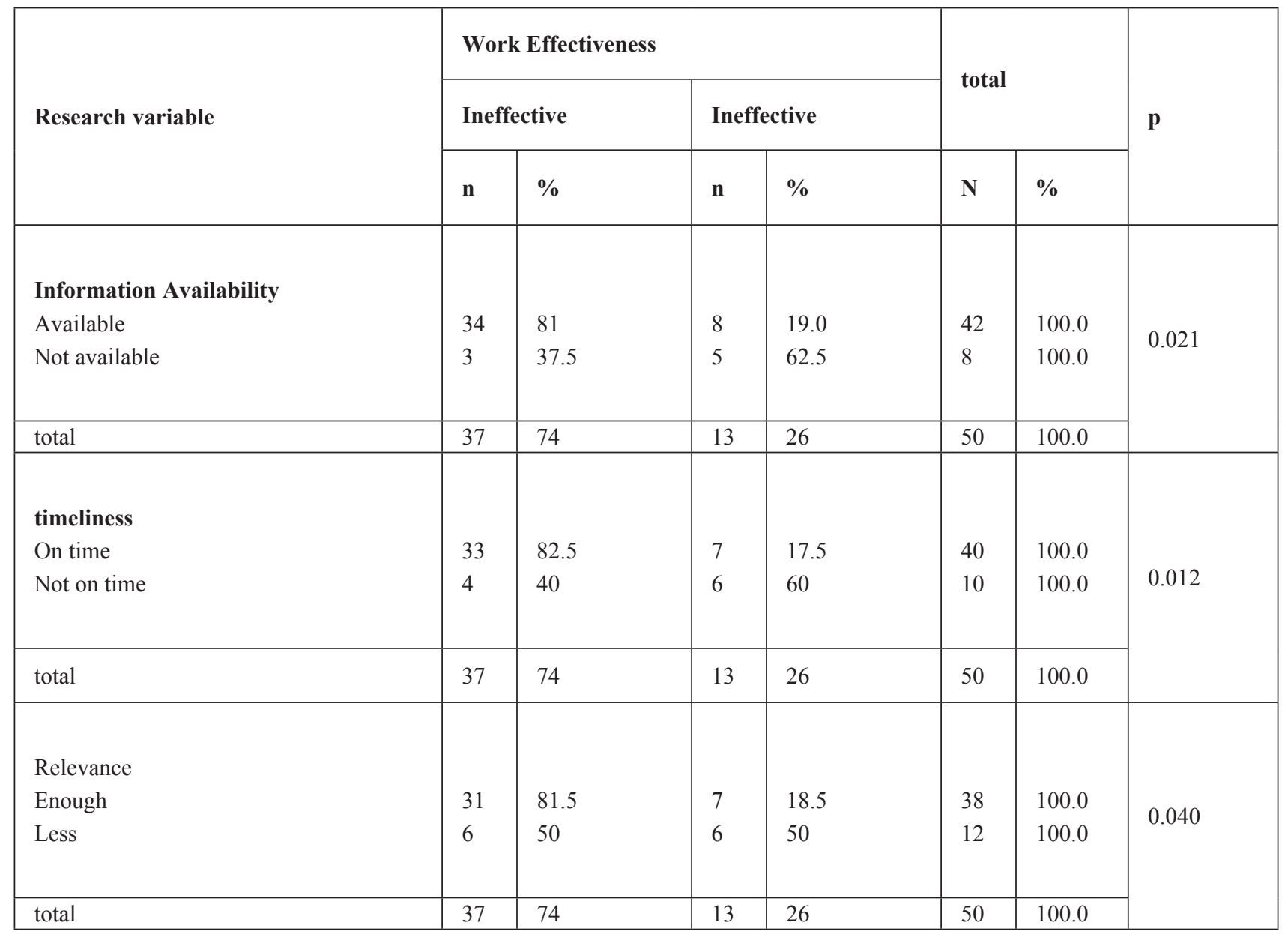

Source: Primary Data, 2020

Table 2 shows that out of 50 respondents the variable Availability of Information and work is effective, as many as 34 respondents $(81.0 \%)$ information is available and ineffective in their work, as many as 8 respondents (19\%). While respondents who stated the unavailability of information but were effective were as many as 3 respondents $(37.5 \%)$ who stated that no information was available and ineffective as many as 5 respondents (62.6\%). Based on the results of hypothesis testing using Chi-Square obtained p-value $(0.02)<\mathrm{a}(0.05)$, proving that statistically $\mathrm{HO}$ is rejected, which means there is an influence of the availability of information on the Work Effectiveness of Employees of public health centers in Ambon City in 2020.

Based on the timeliness variable table 2 shows that of the 50 respondents the information variables were timely and effective at work as many as 33 respondents $(82.5 \%)$ and those whose information was less timely and ineffective were as many as 7 respondents (17.5\%). While information that is less timely and effective in their work is 4 respondents $(40 \%)$ and information that is less timely and ineffective in their work is 6 respondents $(60 \%)$. Based on the results of hypothesis testing using Chi-Square obtained p-value $(0.01)<\mathrm{a}(0.05)$, which means that statistically $\mathrm{H} 0$ is rejected, meaning that there is an effect of timely information on the Work Effectiveness of Employees of public health centers in Ambon City in 2020.

Based on the Relevance variable table 2 shows that of the 50 respondents the variables are quite relevant and effective as many as 31 respondents $(81.5 \%)$ and the less relevant and ineffective that is as many as 7 respondents 
(18.5\%). While respondents who stated less relevant and effective were 6 respondents $(50 \%)$ who were less relevant and ineffective as many as 6 respondents $(50 \%)$. Based on the results of hypothesis testing using Chi-Square obtained p-value $(0.04)<\mathrm{a}(0.05)$, which means that statistically, $\mathrm{H} 0$ is rejected, which means that there is a Relevant Information effect on the Work Effectiveness of Employees of public health centers in Ambon City in 2020.

\section{Discussion}

The effect of health information system (HIS) availability towards effectiveness of public health center officers

Based on the results the study showed that $58 \%$ of respondents expressed employee work in the Public health center quite effectively. From these results can be noted that the availability of information is assessed reasonably available by health officers. Where every time needed information can be easily obtained. The results also show that the availability of information has a meaningful influence with the effectiveness of employee performance in the Health center in Ambon city. This suggests that the hypothesis is acceptable. This is accordance with the research by Hariana (2013) who conducted research in 66 hospitals in Yogyakarta, where the results obtained showed that between the availability of information system in the hospital with the value of use of information system for management function in the hospital there is a meaningful relationship. The availability of information systems provides comprehensive support for patient development and service ${ }^{4}$.

Report/Data that has been recapitulated directly by the officers from the Public health Center to the health office in the form of hardcopy/photocopy. Data transmission from the Public health center of Ambon to the city health office of Ambon can not be sent online still in the form of hardcopy, sometimes also photocopy ". The results of the research conducted by Wijaya (2011), the format of data transmission in the Public health center Tawang also still manually, the form of print out is already determined from the center, the shipment was not directly sent to the national Data Bank but instead sent to the city health office. But for the management of data already use the computer only for the online system of public health center is still constrained because of the absence of adequate Internet network. Given the importance of computers in the SIK process to procure computers in every public health center in certain areas ${ }^{5}$.

The Effect of the timeliness health information system on the work effectiveness of public health center employees

the results indicate that timely information was judged to be timely enough by health workers. This may be influenced by reports of patient data reconciliation that is always collected after the completion of service hours. So that the information is always on time and can be used by health workers. The results also showed that timely information has a significant effect on the work effectiveness of employees at the Ambon City community health center. This shows that the hypothesis was accepted. The results of this study are in line with research conducted by Wekesa (2014) who did research in looking at the utilization of health management information systems in Kenya where the results obtained from 196 respondents 126 showed satisfaction with the timeliness of the systems they use. Timeliness refers to the data that is available on time to make the necessary decisions. More than half of community health workers in Kenya report that available data are always timely and they are able to make decisions based on the data they collect ${ }^{6}$.

The result was also strengthened by an interview with one of the health officers in the Community Health center in Ambon city, who mentioned that the existing system was able to provide timely information. The reports are also timely because each section has been responsible for each.

\section{The effect of health information system (HIS) relevance effectiveness of public}

\section{Health Care Officers}

From the results of the research that has been showed that of the 50 respondents variables are quite relevant and effective, as many as 31 respondents $(81.5 \%)$ and those that are less relevant and ineffective, as many as 7 respondents (18.5\%). From these results it can be seen that the relevant HIS is considered quite relevant by health workers. The results also show that relevant 
HIS has a significant influence on the work effectiveness of employees at Ambon City community health centers. This shows that the hypothesis is accepted. According to Nuraida information is considered relevant if the information is related to the needs of decision making. That is, the information received must be relevant to the problem ${ }^{7}$.

The results of other research by Lestari also show the same results where the information produced is relevant to the needs of management. The form of information provided to the management must be appropriate, precise and detailed so that it can support the management process in making effective decisions ${ }^{8}$. Similar research was also conducted by Chaulagai et al. To see the quality of information system in Srilangka, which shows that $84 \%$ of respondents expressed satisfaction in the information of the relevant aspects of information systems. Relevant information is very useful in the decision making of health care management to set decision ${ }^{9-17}$.

\section{Conclusion}

The research concluded that the effectiveness of employees at the Health center in Ambon city is influenced by the availability factor and will be better if the necessary information infrastructure is available. Information or data that required timeliness of its inputs have an influence on the effectiveness of employees of public health centers in Ambon City. The relevance aspect affects both the effectiveness of the employees of the Health center in Ambon city.

Ethical Clearance- Taken from University ethical committee

\section{Source of Funding- Self}

\section{Conflict of Interest- Nil}

\section{References}

1. Adisasmito, W. Sistem Kesehatan Edisi Kedua. PT Raja Grafindo Persada, Jakarta, Tahun. 2014.

2. Barsasela, D. Sistem Informasi Kesehatan, Jakarta, Mitra Wacana Medika. 2012.

3. Isnawati, K. Implementasi Aplikasi Sistem Informasi Kesehatan Daerah (Sikda) Generik Di Upt. Puskesmas Gambut Kabupaten Banjar.
Journal Of Information Systems For Public Health, 2016; 1, 64-71.

4. Hariana, H. A. 262 Tumbuhan Obat Dan Khasiatnya, Penebar Swadaya Grup.2017

5. Wijaya, C. 2011. Simulasi Pemanfaatan Dynamic Routing Protocol Ospf Pada Router Di Jaringan Komputer Unpar. Research Report-Engineering Science, 2013; 1 .

6. Wekesa, R. N. Utilization of The Health Information Management System By Community Health Workers In The Amref Facility In Kibera, Nairobi County, Kenya. Unpublished Masters Degree In Public Health, Monitering And Evaluation Project, Kenyatta University, Nairobi, Kenya. 2014.

7. Ida Nuraida, S. Manajemen Administrasi Perkantoran, Kanisius. 2008.

8. Lestari, S. Sistem Informasi Klinik Gigi Untuk Evaluasi Pelayanan Kesehatan Gigi Pada Politeknik Kesehatan Depkes Semarang. Program Pasca Sarjana Universitas Diponegoro. 2009.

9. Eka sulistyawaty, Syafar, M., Daud, A., Arsunan Arsin, A., Mallongi, A., Werdyaningsih, E. Change of behavior of ODF through STBM Program in Cempaka Putih Village North Gorontalo Regency, Enfermeria ClinicaVolume 30, June 2020, Pages 396-398

10. D Ogetai, AL Rantetampang, A Zainuri, A Mallongi, The Affecting Productivity of Work Staff at Sub Health Ministry Sub, Province Mimika International Journal of Science and Healthcare, April-June 2018., Vol.3; Issue: 2

11. Muhith A, Winarti E, Perdana SSI, Haryuni S, Rahayu KIN, Mallongi A. Internal Locus of Control as a Driving Factor of Early Detaction Behavior of Servical Cancer by Inspection Visual of Acetic Acid Method. Open Access Maced J Med Sci. 2020Apr 20; 8(E):113-116. https:// doi. org/10.3889/oamjms.2020.4341

12. Chaulagai, C. N., Moyo, C. M., Koot, J., Moyo, H. B., Sambakunsi, T. C., Khunga, F. M. \& Naphini, P. D. 2005. Design and implementation of a health management information system in Malawi: issues, innovations and results. Health policy and planning, 20, 375-384.

13. Anwar Mallongi, Ezra Limbong, Furqaan Naiem, Hasanuddin Ishak, Syahrul Basri, Muh. Saleh, Aminuddin Syam, Laode Asrul. Health risk analysis of exposure to mercury $(\mathrm{Hg})$ and cyanide 
(CN) in Kayeli village communities Teluk Kayeli district Buru regency. Enfermería Clínica Volume 30, Supplement 4, June 2020, Pages 427-430

14. Rosmala Nur, Muh. Asep Dwitama, Muh. Fadly, Nurhaya S Patui, Sitti Radhiah, Elvaria Mantao, Anwar Mallongi,. The Culture and Age of First Marriage on Female Teenagers in West Marawola. Medico-legal Update, January-March 2020, Vol.20, No. 1

15. Kayame, R., Mallongi, A. Relationships between smoking habits and the hypertension occurrence among the adults of communities in paniai regency, Papua Indonesia. Indian Journal of Public Health Research and Development 2018; Volume 9, Issue 1, Pages 332-336

16. Birawida, A.B., Selomo, M., Mallongi, A. Potential hazards from hygiene, sanitation and bacterium of refill drinking water at Barrang Lompo island (water and food safety perspective) IOP Conference Series: Earth and Environmental Science 2018; Volume 157, Issue 1, Article number 012034
17. Russeng, S.S., Saleh, L.M., Virani, D., Latief, A.W.L., Mallongi, A. The investigation of the lactic acid change among employee of national electrical power plan. Indian Journal of Public Health Research and Development 2018; Volume 9, Issue 1, Pages 361-365

18. Darmawansyah, Said, M., Yunus, R., Palutturi, S. Increasing inpatient service quality of using Quality Function Deployment method in Nene Mallomo Hospital of Sidrap Regency, Indonesia. Indian Journal of Public Health Research and Development, 2018; Volume 9, Issue 4, Pages 287291

19. Mallongi, A.,Safiu, D., Amqam, H., Syam, A., Hatta, M., Sutarti, T., Abdul, M., Siyoto, S., Apollo., Modelling of $\mathrm{SO}_{2}$ and $\mathrm{CO}$ pollution due to industry PLTD emission Tello in 2 Makassar Indonesia. Journal of Engineering and Applied SciencesVolume 14, Issue 2, 2019, Pages 634-640 